\title{
13 John Savio's Art as a Part of Early Sámi Decolonisation in the 1920s and 1930s
}

\author{
Tuija Hautala-Hirvioja
}

\section{Introduction}

The objective of the chapter is to discuss the woodcuts made by the first Sámi artist John Savio (1902-1938), who was educated in Western traditions in Norway, and his use of art as a means of decolonisation. His art was inspired by the natural beauty of the Arctic region and Sámi culture, and the Sámi way of life which depended on reindeer herding, fishing and hunting. Savio's art reflected strong personal feelings. He belonged to a minority culture himself. He lived at a time when racism played a central role in science and society in Europe. The decades before the Second World War were harsh for the minorities. The state leaders of Norway wanted all to speak only Norwegian and live the way of the majority. Thanks to his teacher, the Sámi activist Isak Saba (1875-1921), Savio knew about the earlier artists who had depicted the Sámi people and their culture and bravely represented the minority.

John Andreas Savio was born in the small village Bugøyfjord on the shore of Varangerfjord in 1902, but spent his early years in Kirkenes in Finnmark in the northernmost county in Norway. He was descended from Kven and Sámi people (Berntsen \& Parmann, 1980, p. 16). Kvens are an ethnic minority in Norway descended from Finnish peasants and fishermen who emigrated from the northern parts of Finland and Sweden to northern Norway in the eighteenth and nineteenth centuries. The culture of the Kvens is based on Finnish culture and language (Lähteenmäki, 2004, pp. 146-147).

Sámi are the only ethnic group in the European Union to be recognised as Indigenous people. They live and are a minority in four countries: Finland, Norway, Russia and Sweden. There are between 60,000 and 100,000 Sámi, depending on the way they are counted. Sápmi, a Sámi region, extends from central Norway and Sweden across northern Finland to the Kola Peninsula in Russia. There are nine Sámi dialects or languages, and all the Sámi languages are endangered (Lehtola, 2002, pp. 9-11). Two important features related to Sámi culture are traditional handicrafts, duodji, and the Sámi costume, gákti. The Sámi garment is a symbol of a Sámi person's identity. Hunting, fishing and reindeer herding have always been the basis of Sámi culture. Traditionally, Sámi aesthetics and a sense of beauty were joined with practicality and expressed in handicraft, duodji, which was firmly connected with the spheres of life and livelihoods (Lehtola, 2002, pp. 9, 114). The Sámi scholar Veli-Pekka Lehtola emphasises the importance of nature in their culture: 'The Sámi have always relied on 


\section{2}

nature. Nature has provided the sources for both their material and spiritual culture. This base sets Sámi culture apart from industrial or agricultural civilisations' (Lehtola, 2002, p. 88).

When Savio was only 3 years old, his parents died. His grandparents took him into their care. Thanks to his grandparents' wealth, he was given good schooling (Abiel, 1993 , p. 3). In the autumn of 1920, Savio moved to Oslo to complete upper secondary school. At the same time, he made drawings in day and evening classes in the State College of Crafts and Design. However, he could not graduate because he contracted tuberculosis and one of his lungs had to be operated on. After surgery and a period in the hospital, he returned to Kirkenes in 1921 in order to regain his strength, and he stayed in Finnmark until the autumn of 1922 (Nerhus, 1982, 54). After that, he lived for a couple of years in Oslo and later in several villages in Finnmark from 1926-1928. The next years were years of wandering. He lived again in Oslo but visited various parts of Norway, took a trip to the neighbouring countries and later went on a trip to Europe. In the autumn of 1932, Savio had his first solo exhibition in Tromsø (Rasmussen, 2005, pp. 89-90). In 1933-1934, he studied art in Paris, and he held his second solo exhibition in the summer of 1936. In the spring of 1938, the tuberculosis of his early years returned, and he died in Oslo at the age of 36 on 13 April 1938 (Moksnes Gjelsvik, 2012, pp. 43, 144).

Savio worked with many techniques, using both watercolour and oil. He became known for his graphic prints. His main motifs were reindeer, the Sámi and the power of nature. Most of the art in the Savio Collection in Kirkenes is graphic, consisting of a few linocuts with the majority being woodcuts. Both are relief printing techniques. The images are carved into the surface of a plate of wood or linoleum, leaving the printing parts higher level than the surface and removing the non-printing parts. Then the printing parts are coloured with ink, which in Savio's case was black, and printed onto paper (Rasmussen, 2005, p. 14). During the study years at the State College of Crafts and Design in Oslo, Savio learned the methods and history of Western fine art. However, his cultural background had been deeply influenced by minorities, and his native language was Sámi (Bang, 2002, p. 10). In Bugøyfjord, the people spoke Sámi and Finnish, as well as a mixture of Russian and Norwegian due to Russian Pomor trade. In secondary school, fine arts and the Sámi identity became stronger, and the teacher Isak Saba encouraged Savio to continue painting (Moksnes Gjelsvik, 2012, pp. 22-25). By heritage, Savio was Sámi and Kven, but his education and artistic training were completed at institutions set up by national majority populations.

This chapter is organised as follows. After this brief introduction to Savio's life, I present the major themes of the chapter. I then explain my subject position and overlapping multimethodological approach. Due to Savio's art being situated in the contexts of Norwegian art and Norway's minority policy, I expand on these issues by dealing with racial ideology and the colonial language question, as well as Savio's mentors who contributed to his Sámi and artist identities. In the last section, I analyse his art and focus on the decolonisation aspects of it. The conclusion argues that Savio was a decolonising pioneer who opened the way for contemporary Sámi artists and that the same kind of decolonisation with art occurs today among other Indigenous people.

\section{Exploring the Concepts and Subject Position of the Researcher}

This research is based on an approach that combines Indigenous and Sámi research with that of art historians such as Ernst Gombrich and Erwin Panofsky on iconography 
and Mieke Bal on semiotics and narratives. Today, it seems to be possible to connect both traditions-Indigenous knowledge and Western academic approaches-to knowledge creation (Ahvenjärvi, 2017, p. 54). Sámi scholar Elina Helander-Renvall (2016, p. 141) writes: 'Contacts between science and Indigenous knowledge can be referred to as postcolonial moments. . . . During postcolonial moments, cultural and human diversity has been taken into account, and even respected'. Savio's background was in the Sámi culture and its world view. He studied Western fine art and knew Western art history well. The picturing of different subjects, such as a landscape or a human being, is linked to learning and earlier ways of seeing and picturing, as well as the current ideological and social history and other relevant contexts; thus, a picture is always a subjective creation. The artist's cultural background and individual life history is included in it: his or her memories, emotions and experiences form a subjective relation to the subject to be pictured (Panofsky, 1972, pp. 5-17). The means of expression chosen by the artist is also one of the essential factors: a drawing or graphic depicts different objects as lines, but a relief print consists of masses and often is in black and white. A style or mode of expression is also involved; this requires an artist to study the subject from a certain point of view (Gombrich, 1991, pp. 73-75). Thus, Sámi and Indigenous research, coupled with critical art history, enriches interpretations. According Bal (2020), the confrontation with traditional art history makes the tensions and collaborations between semiotics and art history more productive than would either a slavish traditionalism or a total rejection of such a tradition.

According to the Indigenous and Sámi scholar Rauna Kuokkanen (2007, p. 146), decolonisation refers to a process that seeks to dismantle various forms of power, such as the hidden means of power in institutional and cultural structures. However, decolonisation also refers to the intellectual situation whereby the majority and the dominators' ideas caused the colonised minorities to feel inferior (Waziyatawin et al., 2005 , p. 2). This refers to the conception of the colonising of the mind described by the Kenyan novelist and postcolonial theorist Ngũgĩ wa Thiong'o in his book Decolonising the Mind: the Politics of Language in African Literature (1986). He emphasises the importance of language, which is an inseparable part of a community of human beings with a specific form and character, a specific history, a specific relationship to the world. Kuokkanen discusses the same situation that occurred with how the colonial power dealt with Sámi languages and culture. This inner or mind colonisation of Indigenous and Sámi people had been a long process. Thus, it became necessary for the minorities to have the right to use their own language and have the opportunity to build up their own culture and identity (Kuokkanen, 1999, pp. 96, 109).

Considering the aforementioned background, an overlapping multimethod approach that combines Indigenous and Sámi research methodologies and art history is the most appropriate way to interpret Savio's art. Theories such as feminist, posthumanist, race and class theories share the same perspective as Indigenous research in that knowledge in itself is not seen as the ultimate goal (Wilson, 2008, p. 37). All these novel critical ways of thinking enrich and broaden traditional scientific understanding and interpretation of art.

To improve my understanding of Indigenous research, For Indigenous Eyes Only: A Decolonization Handbook was a good work to start with. I learned to identify and avoid hidden colonial aspects by answering the questions in the handbook, which I considered particularly important. Colonisation also refers to the situation of Indigenous people, when the colonisers' power came at the expense of Indigenous lands, resources, lives and self-determination (Waziyatawin et al., 2005, p. 2). The concept 


\section{Tuija Hautala-Hirvioja}

'Indigenous peoples' was introduced in the 1970s within the struggles of the American Indian Movement and the Canadian Indian Brotherhood. Indigenous scholar Linda Tuhiwai Smith (2012, p. 7) writes: 'The term has enabled the collective voices of colonised people to be expressed strategically in the international arena'. She also comments that Indigenous people belong to a network and continues:

They share experience as peoples who have been subjected to the colonisation of their lands and cultures, and denial of their sovereignty, by a colonizing society that has come to dominate and the shape and quality of their lives, even after it has formally pulled out.

However, the facts are that colonisation is still going on, established states continue to control Indigenous peoples' lives, and decolonisation remains a significant problem (Kuokkanen, 2007, p. 146).

When applying and using Indigenous research as a perspective or method, it is ethically correct to present one's background, relationship to the research subject and motives (Chilisa, 2012, pp. xix-xx; Kuokkanen, 2007, pp. ix-xxii; Smith, 2012, pp. 222-232). This is essential because all ideas, knowledge and interpretations are developed through relationships. One of the most critical aspects is the ethical responsibility to ensure that knowledge and people are not exploited (Kovach, 2010, p. 36; Wilson, 2008, p. 134). Researchers must understand that their own experiences, education and world views influence their research. It is always necessary in Indigenous research to understand and articulate one's own place and limits (Seurujärvi-Kari, 2011 , p. 35). One must position oneself to show the interpretative lens, to open up one's intentions and to be able to reflect (Chilisa, 2012, p. 177; Kovach, 2010, p. 46).

My paternal ancestors were Sàmi, but their Sámi language changed to Finnish at the beginning of the nineteenth century, and the following generation built a farmhouse in Alakurtti. After the Winter War (1939-1940), Finland had to cede to the Soviet Union the eastern part of Salla (in northeastern Lapland) and the area where my father's family lived. After the Second World War and until his death in 1970, my grandfather was a fisherman on lake Inari in the Sámi area. I was born in Oulu, about 500 kilometres south of the Sàmi area. Since 1970, the Sámi language has been taught at the University of Oulu. Before my art history studies, I studied in Oulu at the Teachers' Training College (1976-1979), and I had Sámi fellow students. During my years of study, my methodological thinking has evolved based on a qualitative humanistic tradition. At the end of the 1970s, I became aware of concepts such as otherness, hegemony, Eurocentrism and, shortly afterwards, feminist art history and other critical voices that are part of the humanities. I studied art history and ethnology, which also dealt with the Sámi cultures of Finland. In 1984, I moved to Rovaniemi in the Arctic Circle area of Finland, not far from the Sámi area.

Through writing my doctoral thesis, Lappi-kuvan muotouminen suomalaisessa kuvataiteessa ennen toista maailmansotaa ['Shaping the Image of Lapland in Finnish Visual Arts before the Second World War, 1999'], I became familiar with how Scandinavian artists depicted Sámi people and their lives. I got to know art created by the Swedish painter Johan Tirén (1851-1911). He saw the hard life and subjugation of the Sámi and depicted the Sámi appreciatively. He felt sympathy for the Sámi and pictured some of their tragic events, such as in his Efter snöstormen [After Snowstorm] 
(1885). With his political painting Lappar tillvaratagande skjutna renar [Sámi Capturing the Shot Reindeer] (1892), Tirén wanted to defend the Sámi right to herd their reindeer in the traditional fashion. At that time, it was legal for farmers to kill stray reindeer. Thanks to his painting, the law was changed, and it was then forbidden to kill reindeer (Hautala-Hirvioja, 1999, pp. 46-47). I continued my academic research by concentrating on art and culture in the Euro-Arctic region. I was an active member of the Sámi Art Resort Project (SARP) at the Arctic University of Norway in Tromsø (2010-2016), and I published some articles about Sámi visual art. I was one of three curators of Saamelaista nykytaidetta, Dálá Sámi dáidda, Sámi Contemporary (20142015). ${ }^{1}$ I studied Sámi research (2017-2019) at the University of Lapland to improve my knowledge and understanding of Sámi culture. In spite of all my studies, however, my position in relation to Sámi culture remains that of an outsider.

\section{Towards Overlapping Approaches to the Research}

I have learned to understand Sámi history and culture, and their special relationship with nature and land through literature published by Sámi scholars, such as Elina Helander-Renvall, Veli-Pekka Lehtola, Päivi Magga and Irja Seurujärvi-Kari, and through lectures given by Sámi researchers including Rauna Kuokkanen, Anni-Siiri Länsman, Sigga-Marja Magga, Klemetti Näkkäläjärvi, Rauna Rahko-Ravantti, Jarno and Sanna Valkonen, and many others. Panofsky's iconology has three levels: the first and second levels concentrate on description and interpretation of visual art, while the third level enables one to identify the meaning of an artwork. Here, the researcher must look for more contexts, such as the social, educational and political systems and the religious, symbolic and mythical atmospheres that existed during the artist's lifetime.

The researcher must also possess the synthetic intuition to draw conclusions (Panofsky, 1972, p. 66). Indigenous research requires the presence and understanding of symbolic and metaphorical representations. For me, semiotics offers a more interdisciplinary version of iconology, an extended way of asking questions about what works of art mean and how they go about creating or expressing these meanings (Bal \& Bryson, 1991, p. 178). In addition, it is reasonable to approach traditional knowledge and Indigenous art through the senses and intuition (Kovach, 2010, p. 41; Wilson, 2008, p. 55). The third level of my analysis relies on a piece of research respecting Indigenous society (Wilson, 2008, p. 59), and my study aims to benefit the Sámi and other Indigenous people and offer the new knowledge about early Sámi fine art.

Therefore, my goal has been to offer new knowledge about Savio's art and his intentions. To do that, I have had to gain a holistic understanding of the life of Indigenous people. In their world view, human beings are part of nature, equal with all living things on the earth without distinction. In contrast, Western philosophy considers humans and nature to be in opposition to each other. Christian belief has separated the body and soul, and considered the individual as the basic building block of society (Smith, 2012, pp. 50-51). The Indigenous scholars Shawn Wilson (2008, p. 59) and Margaret Kovach (2010, p. 47) have offered the principles needed to follow Indigenous research and to respect the Sámi world view by adhering to ethical responsibility and sensitivity. Open discussion is considered by many Indigenous and Sámi scholars, such as Bagele Chilisa (2012, pp. 203-211), the best method for collecting research material. Equal, honest and respectful dialogue creates the best opportunities to understand one another well (Helander \& Kailo, 1999, pp. 21-23; Valkonen \& Valkonen, 
2018, pp. 19-21). In my case, this open discussion will occur between earlier research on and interpretations of Savio's art and my interpretation of his art.

Although Gombrich wrote about Western art, he presented some general ideas that also apply to handicrafts, folk art and Indigenous art. He posited that there is no reality without interpretation, that our eyes see the world in the same way our ancestors did and that our brains interpret nature and objects like the brains of earlier generations (Gombrich, 1991, p. 21). Panofsky developed a method for interpreting Renaissance art and found that analysis is comparative when looking for similarities and differences amongst artworks. An important aspect of iconological analysis is comparison with textual sources. With the rise of new critical theories, scholars of art history began to reject the traditional methods. In particular, they criticised iconological analysis arguing that it was limited and descriptive in nature (D'Alleva, 2005, p. 25). According to Bal (2020), questioning traditional iconology makes the collaborations between semiotics and art history more productive than they would be with either a slavish adherence to traditionalism or a total rejection of such a tradition.

As a flexible humanist, I employ some of Bal's ideas about a hermeneutic approach to interpret art, looking for and testing different contexts. This is known as a hermeneutic cycle where interpretation of details affects the interpretation of the entire phenomenon. The reviews of these interpretations deepen our understanding of the content of art (D'Alleva, 2005, p. 128). The same occurs in Indigenous research, as the scholar Shawn Wilson notes (2008, p. 102): 'things have to be put into context', and their context must be respected in order to understand 'how the knowledge is hermeneutic'. The second level of Panofsky's iconology, which is dealing with subjects and their symbolic meanings, requires familiarity with the artist's culture (Panofsky, 1972, p. 54). Thus, my knowledge of Sámi culture and history has been helpful in conducting this study.

\section{The Sámi-An Ancient Relic and the Norwegianisation Policy}

Savio lived and produced his art during the difficult years before the Second World War. At that time, a racist attitude and ideology promoted the belief that ethnic groups of humans possessed different behavioural and intellectual traits depending on their physical appearance and that humans could be categorised based on the superiority of one race over another (Isaksson \& Jokisalo, 2005, p. 18). In Scandinavia, the Sámi and Finns were thought to belong to the Mongolian race. As early as in 1871, the Finnish writer and geographer Zacharias Topelius wanted to separate the Sámi and the Finns. Twelve years later, in 1893, he wrote in his book Suomi 19:nnellä vuosisadalla [Finland in the 19th Century] that was aimed at foreign readers: 'They call themselves Sámi and think themselves as relatives of the Finns. The Finns do not want to accept this relationship which is rather distant. A Sámi is not a step-brother of a Finn, or even a cousin' (Topelius, 1898, p. 56). This was indicative of the situation in all the Scandinavian countries: the position of minorities was inferior.

The descriptions of the Sámi were stereotypical in the books written at the end of the seventeenth century, and particularly in the travel books during the eighteenth century. Later in the classical racial classification, the Sámi were assigned to the Mongolian race and were described as being a degenerated or malformed, non-European race (Isaksson \& Jokisalo, 2005, pp. 62-64). The basis of this attitude was an oversimplified version of evolutionary theory. This so-called vulgar Darwinism was characteristic 
of the colonial spirit and became visible in the public debate and was accepted as part of everyday life (Solbakk, 2006, p. 70).

A strong, systematic policy of assimilation was pursued in Norway at the beginning of the nineteenth century; its aim was to assimilate minorities into the majority population (Isaksson \& Jokisalo, 2005, pp. 206-207). In 1851, all schools received orders to use Norwegian as the language of instruction; only Bible-based religious education could be conducted in Sámi and Kvens. From the 1850s onwards, teachers were paid a bonus in addition their salary that depended on how well they succeeded in their Norwegianisation work and teaching Norwegian to their minority pupils (Solbakk, 2006, pp. 69-70). Lehtola (2002, p. 44) stated: 'The power of Norwegianization policy lay in the fact that it extended into the realm of legal application'. Assimilation policy in Norway and Sweden was also part of a broader nationalistic political strategy. The Sámi and Kvens were thought to be a menace to security. First, both countries were afraid of the influences of Russia and later communism and the Soviet Union (Solbakk, 2006, p. 72).

In 1898, a new law in Norway prohibited the use of the Sámi language in schools and in student boarding houses. This law was only repealed in 1959 (Lehtola, 2002, p. 45). The law on land ownership in 1905 connected to language by assigning a Norwegian name to properties and linked ownership to language proficiency (Ranta \& Kanninen, 2019, p. 28). All people had to learn Norwegian and take Norwegian names to be able to buy the lands which they cultivated or used. In keeping with the active colonialist beliefs, minorities had to be assimilated into Norwegian society. Passive or implied colonialism meant that, by civilising these minorities, it would be possible to absorb the Sámi and Kven people into the Norwegian culture and substitute the Norwegian language for their native languages (Lehtola, 2002, p. 45).

At the beginning of the twentieth century, the protomorphic theory of the Sami became the prevailing theory in Scandinavian race science, especially as it was supported in Norwegian anthropology (Isaksson, 2001, p. 381). It was a part of Darwin's theory of evolution, according to which the Sámi were regarded as a cultural and biological remnant in the history of evolution like a relic from prehistory, where higher cultures had evolved further than the Sámi. At the same time, there was the belief that it would be possible to educate the primitive Sámi and to elevate them to the same level as Norwegians. From the end of the nineteenth century to the Second World War, intermarriages between the northern Scandinavian race-to which the Norwegians, Swedes and Danes belonged_-and the Finns, Kvens and Sámi were rare. Moreover, the Finno-Ugrian peoples ${ }^{2}$ were believed to be simple and weak people because of their Mongolian roots. Mixed race people were considered as degenerate and weak (Isaksson, 2001, pp. 164-170).

The Norwegianisation policy was strong and intensive in Savio's home area in Finnmark, where he had spent his childhood and youth. The first main trend was settlement and economic policy; the aim was to establish Norwegian agricultural colonisation and farming in the eastern part of Sápmi, the main Sámi area (Lehtola, 2002, p. 44; Solbakk, 2006, p. 70). Another aim was to strengthen Norway's power in Finnmark because the area was strategically important in its relations with Soviet Union. The main reason was to have a genuine and reliable Norwegian population living in this border territory. That is why the Norwegianisation policy was directed not only towards the Sámi but just as much towards the Kvens (Solbakk, 2006, p. 71). The second main trend of the Norwegian government was to establish an education policy to eliminate the Sámi language from all schools (Lehtola, 2002, p. 45). 
At the same time as this severe Norwegianisation was being imposed, the Sámi began to understand the significance of pan-Sámi national cooperation. In Norway, five local Sámi associations were founded in the south. In the 1910s, Sámi organisations began to be established in Finnmark, Savio's home county (Lehtola, 2002, p. 46). On 6 February 1917, the first Sámi National Congress was convened in Trondheim in Norway (Solbakk, 2006, p. 75). Today, that date is celebrated as the Sámi national day.

\section{Savio's Mentors and Models}

John Savio's first drawing teacher was Isak Saba, who was an editor, writer, Sámi activist and politician. Saba is considered to be the national poet of the Sámi. He wrote the lyrics of Sámi soga lávlla ['Song of the Sámi People'], which was made the Sámi national anthem in 1986. He was the first Sámi to be elected to the Norwegian Parliament, where he represented Finnmark from 1906-1912. Saba tried to promote the affairs of Sámi and inform his people about the discussions and activities of the Parliament (Kent, 2014, p. 75; Kulonen et al., 2005, p. 370). He fought all of his life for the sake of the Sámi. He tried to awaken the Norwegian people to take responsibility for the cultural oppression of the Sámi. At the same time, he was equally committed to the Sámi themselves taking up the fight against injustice and oppression (Store Norske Leksikon, 2020).

Teachers like Saba were important, but also early Sámi writers were an integral part of Sámi awakening (Lehtola, 2002, p. 46). Lehtola (p. 48) pointed out their position:

Although in their works, Johan Turi, Pedar Jalvi and Anders Larsen depicted the situation in Sápmi each in their own way, they also created a new concept of Sámi thought and self-image-for outsiders and for Sámi themselves. Through their literary means they tried to awaken Sámi to the recognition of their own uniqueness.

Thus, as a result of Saba's teaching of an influence on Savio, he became proud of his Sámi background and culture. According to Savio's good friend Hans Nerhus (1982, p. 31), especially in Oslo, the artist wanted to be known as a Sámi man.

Saba was also a family friend of Savio's grandparents, and he knew that they hoped their daughter's son would become a priest. The grandparents were believers, and they belonged to the Laestadian religious movement, which is a Nordic religious movement bearing the name of its founder, Sámi minister Lars Levi Laestadius (1800-1861). According Sandra Wallenius-Korkalo (2014, p. 111),

the movement originated in the northern parts of Finland and Sweden around the mid-1800s and rapidly spread through the North Calotte among the Indigenous Sámi population, as well as among the Finns. . . . Laestadianism has had a profound religious, cultural and social impact in the area.

Even today, Laestadianism is a popular and very strict and conservative revivalist movement. It opposes the liberation and ordination of women, sex before marriage, birth control, movies, theatre, opera, alcohol, dance, television and make-up, and even competitions are forbidden. They believe that a human being has to be humble before God's eyes (Alho et al., 1999, p. 258). As Lehtola (2002, pp. 38-39) states: 'The 
Laestadian faith has from its beginning been an important part of Sámi culture.... In the strict Laestadian world view, many Sámi found a solution to the difficulties brought by the insecure times'. Laestadianism seems to have been a protest against the official church, although the movement remains inside of the official Lutheran Church and its government. Many Sámi still recognise Laestadianism as their spiritual home (Kulonen et al., 2005, p. 170).

Savio's grandparents encouraged him to create art; it was a good hobby. However, to be an artist was not considered an acceptable occupation. The artist's profession and way of living were considered bohemian and too liberal, which made it suspicious and sinful. After becoming aware of Savio's gifts, Saba encouraged him to try the visual arts. Savio admired his teacher, praised and often thanked him (Moksnes Gjelsvik, 2012, p. 25). Nerhus (1982, p. 39) recalls their relationship:

These two Sámi art characters were completely different but from the very beginning there was a warm feeling of togetherness. Savio admired his sympathetic and understanding teacher and older friend, and Saba had no lack of admiration and great hopes for his young friend and pupil.

Savio moved to Oslo at the age of 18 and started to study art, partly in school and partly on his own. At that time, the woodcut technique was not taught in art schools in Norway, so he must have become acquainted with it on his own. During his childhood, he had learned to use a knife. Every Sámi boy was taught to make duodji, the old, traditional Sámi handicraft. The hard materials of duodji-wood, bone and antler-were for men and were decorated by carving with the tip of a knife or another sharp object. Carving was done by drawing a groove or by engraving a hole or dot with the tip of a knife (Kulonen et al., 2005, p. 75). It was quite easy for Savio to engrave wood and lino plates. However, to make art is different than producing practical objects, and Savio began to study the graphic art of Albrecht Dürer, but he was interested in both older and newer graphic art, as well as Japanese wood engraving (Lorck, 2002, pp. 19-21).

In Norwegian art of the 1920s and 1930s, the woodcut was not a popular technique. Only two Norwegian artists, Edvard Munch and Nicolai Astrup, made woodcuts and used relief print techniques, and they became important models for Savio's graphic work. Munch had learned graphic techniques himself, and he studied Japanese wood engraving. He had lost his mother as a child at the age of 5, and later her two sisters passed away. Loneliness, sickness and pain were present in Munch's life and art (Stang, 1980, pp. 31-33, 127-128). Savio had similar experiences in his childhood, so it was easy for him to identify with Munch's themes and expression. Astrup lived most of his life in Jølster village, a local agricultural community. With the exception of a few pictures, his motifs were all from his home region. He began to make colour prints by using only one plate. His art was considered regional or local (Danbolt, 2001, pp. 219-220). Astrup's artworks inspired Savio's interest in graphically depicting his northern home area and the life of local Sámi people. Later, Savio developed his woodcut technique and studied Malcom C. Salaman's book The Woodcut of To-Day at Home and Abroad published in London in 1927 (Lorck, 2002, p. 23).

Savio became acquainted with the first Sámi writer, Johan Turi (1854-1936). In 1910, Turi published Muittalus samiid birra (An Account of the Sámi). In this book with illustrations, he presented a comprehensive and understandable look at Sámi life. 
As Kathleen Osgood Dana (2003, p. 201) writes: 'To discuss the Sámi, Turi chose a discourse that effectively forced him to negotiate between dominant Western textual paradigm and the Sámi oral tradition'. Turi $(1979$, p. 13) had a clear purpose in his book which he stated at the beginning of the text:

I have thought that it would be a good if there is a book in which had been told everything about Lapp ${ }^{3}$ life and circumstances.... Everything is twisted for the Lapps when there is trouble between the farmers and the Lapps in Norway and Sweden. In the book everything must be written and explained so that it is clear to everyone. And it will be good for the Lapps themselves to hear the circumstances of the Lapps.

His original intention seems to be to inform the authorities about Sámi life. With his book, Turi showed that art and culture are good tools for changing colonised minds and restoring the sense of self-worth and the dignity of the identified.

Turi's book is unique in terms of both its language and content. It was the first non-religious book written in the Sámi language by a Sámi person. Turi wanted to correct the mistaken ideas about the Sámi and show all the essential aspects of the Sámi people's way of life, such as hunting, fishing, life with reindeer and summer and winter migration. The text of his book is complemented by a picture atlas drawn by him. Turi's pictures have been noted as containing features of traditional Sámi engraving and prehistoric rock art. He depicted people and animals as stylised signs, but he managed to create an authentic atmosphere that captured the essence of Sámi life in his drawings. Later, Turi published more two books and continued to paint until he died in 1936 at the age of 82 (Hautala-Hirvioja, 2014, pp. 15-18).

Turi's illustrations have been evaluated in the canon of Western art history. During the last decade, his art has been reinterpreted in terms of its perspectives on Sámi life. It has been noted that Turi was a great observer. His way of depicting reindeer with small details is considered to be excellent. According to the art history professor Svein Aamold (2017, p. 74), 'The size of their antlers, their calving, or details of the surroundings such as open or frozen rivers and lakes, the presence or absence of snow on the ground, the herders' equipment, etc. are all depicted in Turi's work'. Savio developed his engraving technique to be able to present nature, animals and humans in a detailed and expressive but credible way. Surely, Turi's art encouraged Savio as an artist and as a Sámi.

\section{Landscape and Nature of Finnmark in Savio's Art}

Savio also painted with watercolour and oil, but his main technique of making art was the woodcut, and he is known for his relief graphic works. This choice may be due to the Sámi culture, in which duodji traditional handicraft is the important cultural mark of identity. Carving or engraving is one of the oldest ways to decorate tools and artefacts. This method was present in Savio's life and is still in use today when a duodjare, a Sámi craftsman, decorates hard material, such as bone, antler or wood, to create artefacts (Sunna, 2006, pp. 7-9). I have heard that, for a Sámi boy, a knife was the first gift, and learning how to use it and whittle was the first skill.

A total of 151 motifs or versions are known, according to the Savio Museum (Rasmussen, 2005, p. 14). Of this, only a few are linocuts, while the majority are 
woodcuts. His main themes are scenes from Sámi and north Norwegian life, the interplay between humans and nature, and landscapes. There are some landscapes from the southwestern region of Norway because, in 1933, Savio lived for a short time in Trondheim (Rasmussen, 2005, p. 90). Many of his watercolours and oil paintings were destroyed during the Second World War, when the cities Bodø and Narvik were bombed, and at the end of war when the whole of Finnmark was burnt by German troops (Nerhus, 1982, p. 78). Luckily, most graphic collectors lived in the big cities in southern Norway and abroad.

Savio's main motifs were Sámi people in a variety of situations and northern animals with the Arctic and northern landscapes as a background. In addition, the villages, sea coasts with fishermen and their boats, and the fell scenery of northern Norway, but also the mountain scenery of Romsdalen in southwestern Norway, were depicted in his work. Landscape and nature are important and essential for Sámi identity. The modern world with mining companies, tourists and expanding agriculture has challenged the former and traditional lifestyle. There were more and more conflicts between the economies of the majority and minority populations (HautalaHirvioja, 2014, pp. 30-31). The traditional Sámi way of life began to change at the end of the nineteenth and beginning of the twentieth century. Nature and Sámi culture, which had important roles in supporting the identity of Sámi people, were significantly affected by the advance of the modern world.

Finnmark, especially the coastal area of the Sea Sámi culture, was Savio's milieu during his childhood and youth. As a young adult, he lived in the fell area in Karasjok and Tana, and he was acquainted with the way of life of the Reindeer Sámi (Rasmussen, 2005, p. 89). Savio was a cultural insider in Sáminess and the Sámi relationship with nature and land. Despite the fact that Savio lived some years in Oslo and travelled abroad, he always returned to the north. According to Sámi scholar Elina HelanderRenvall (2016, p. 65), 'On their own lands the Sami feel themselves safe and experience a continuation of life through generations. ... Those places or lands, to which Sami are traditionally connected constitute a home and an important identity marker for them'. The nature of the Sámi has been learned in everyday practice and as part of the community, so there is no difference or contradiction amongst knowledge, actions and values. Thus, no distinction has been made between nature and culture, which is why the Sámi lifestyle is a nature-conscious, nature-sensitive and site-specific nature-culture (Valkonen \& Valkonen, 2018, p. 9). It was in this culture that Savio grew up.

According to the traditional Sámi world view, man is not the centre of the universe nor can he stand above nature, but he is part of nature and dependent on it. The relationship is equal and respectful (Helander, 2000, p. 171). For a Sámi person, a landscape is not only an object for viewing or acting upon, but also his companion, such as another person. According to SIIDA National Museum of Finnish Sámi researcher Päivi Magga (2013, p. 11), a landscape is not valued on an aesthetic basis; rather, its beauty and goodness are dependent on its profitableness-a beautiful lake is full of fish, and a beautiful slope is easy for reindeer and humans to walk. A Sámi landscape also includes an invisible and immaterial dimension arising from the Sámi world view. Magic landscapes - sacred places, sites of sacrifice and graves-have connections with religiousness. A mythical landscape conveys stories about the birth of different types of landscape, amongst others. Together, they form a cognitive landscape, which helps humans to interpret and understand a landscape. These experiences have been passed from one generation to another through Sámi oral tradition (Magga, 2013, p. 11). 


\section{2}

Tuija Hautala-Hirvioja

In Savio's landscape woodcuts, such as Godveir [Fine Weather], Forsommer gida [Early Summer] and Sommer Geassi [Summer], the landscape is beautiful because the weather is good and life after the cold winter is easy. Miljö I [Environment I] represents harmony between the Sámi and nature, but also reflects the positive connections between two different Sámi ways of living: that of the Sea Sámi and the Reindeer Sámi. Both groups lived in close connection and relation to nature: one was based on fishing and the sea, and the other reindeer and the fells. In the woodcut, the Reindeer Sámi with his dog, reindeer and sled stands on the top of the hill on his way to meet the Sea Sámi by the coast. In the 1920s and 1930s, there was the advent of the existential question in art: What is the meaning of life, and what is the position of human beings? (Danbolt, 2001, p. 230). Savio confronted the same question but from the Sámi point of view: When is a Sámi feeling his deepest existence and harmony? It appears that Savio believed that a Sámi person seemed to be happiest as a part of nature when the weather is good. Sometimes, however, the relationship could be dangerous or require a lot of hard work with reindeer herding or fishing and hunting.

Savio found the ways to describe what he felt were the important places, memories and experiences through his Sámi life and nature, but also through Western art. Artist Nicolai Astrup's regionalism and the examples of his graphic prints encouraged Savio to depict the Arctic and north landscapes, sea coasts and small cities. The strong, expressive and vivid compositions of Edvard Munch's woodcuts influenced Savio's carving and prints. The atmosphere and content of Savio's landscapes and depictions of the villages are unique as in his Israel Lønbomsplass [Israel Lönboms Square]. The woodcut offers a description of everyday life in Kirkenes drawn from the veranda of the Heimen hotel in 1937. There are also village views from Svolavaer on Lofoten and from Tromsø (see illustrations in Abiel, 1993; Berntsen \& Parmann, 1980; Rasmussen, 2005). Savio was an insider as a describer of the identity of these cities and villages. This existential involvement is the most profound kind of sense of place: Savio experienced a place to be his own, and he felt he was a part of the experienced place (Relph, 1986, pp. 49-50). This was a natural outgrowth of Savio having grown up in a home deeply rooted in Sámi culture and the Arctic landscape (Rasmussen, 2005, p. 12).

\section{Sámi and Their Way of Living in Savio's Art}

In many woodcuts, Savio depicted scenes and events from everyday Sámi society. The people are in a variety of situations, working in reindeer herding or spending their leisure time playing cards or drinking coffee beside an open fire. The interplay between human beings and nature is a recurrent motif in his artwork, with the Arctic landscape as a background (Gullickson \& Lorentzen, 2014, p. 11). In Savio's art, the Sámi have their traditional costumes which are possibly the most important mark of their culture and identity. The costume has been said to be another skin for the Sámi, and it is one of their most distinct symbols. Lehtola (2002, p. 12) states: 'The design and decoration of the clothing differ for each place. From general distinguishing features of the garment, a Sámi traditionally identifies the other's home area and, from subtle differences, even their home village and family'. In earlier times, the Sámi wore their traditional costume every day, but that eventually changed to where they only wore them for their celebrations (Kulonen et al., 2005, p. 53). 
The Sámi were often stereotypically portrayed as either an innocent people of nature or as a primitive and vanishing nation, and they were mainly depicted only in terms of being the objects or romantic themes of art and literature. Savio wanted to show them as human beings and depicted their everyday life with both positive and negative emotions such as love, trust, anger, frustration, jealousy, loneliness and hope.

His Sameganda [Sámi Boy] represents a child in Sámi costume sitting with a reindeer horn, perhaps playing with it and at the same time learning the skills he will need as an adult. In the woodcut Gandak suopanin [Boys With Lasso], older boys are training to use a lasso, which is one of the most essential skills in reindeer herding. Three boys are running with a reindeer horn on their heads and one tries to rope them. Savio made many woodcuts which showed Sámi working with a lasso. Compositions of these pictures are vivid and full of movement, and even the surrounding landscape and sky add to the dynamic situation. Almost always, there is a dog to help the reindeer herder. Savio also created images of skiing and wandering Sámi, and the Sámi always have a loyal and trusty dog with them. The Sámi families had several dogs to help to take care of reindeer, but they were also treated as friends and even as members of the family.

The landscape with Sámi reindeer herders has been described as an open and unrestricted space surrounding people, animals and the entire culture. A sense of timelessness-but also the past, present and future-exist on the highlands and fells. Landscapes and open spaces are important for the Sámi. Expanses open places and spaces, and the wind moves air, smells, sounds-the presence of life-through these expanses (Bergmann, 2009, pp. 154-155). The woodcuts of the Sámi people in nature with their reindeer or moving from place to place can be interpreted as Savio's intention to show that their livelihood and way of living is closely associated with their special skills and knowledge of nature. According to the curator Sigrun Rasmussen (2005, p. 13): 'In Gumppet, sápmelas, heargi [Wolf, Sámi, Reindeer], this is shown in the man herding his flock; he is wearing a kofte [Sámi Tunic] and carries his work tools: knife, lasso, staff and gun'.

With the choice of this motif, Savio wanted to show the versatility of Sámi culture. Of course, he also wanted to represent the reindeer herder's work as an equally important part of life amongst the Sámi people as the life of Norwegian workers and farmers. The Sámi people he portrayed are strong and skilful in their work. In the 1920s and 1930s, the so-called social romance movement prevailed in Norwegian art, and according to this style, the main theme was the handsome, young and strong worker (Danbolt, 2001, p. 284). In addition to his other aims, Savio wanted to challenge the stereotypes and misrepresentations of race theory and to describe the Sámi as anything but deformed, lazy, naive and primitive. He depicted the work of reindeer herders; for example, catching and herding reindeer, or driving away wolves.

Savio also portrayed adult Sámi in their leisure time sitting by a campfire, being friends or being in love as in the woodcuts To Guoktes [The Sámi Pair] and Gánda ja Nieida [Boy and Girl]. These two woodcuts appear to be portraits of marriages as the couples are wearing better clothes. Such rites were an important part of community life. However, it is difficult to trace the manners and traditions of old Sámi religious beliefs because of Christian missionising in the 1600s and 1700s. Many old elements continued to survive even until the 1800s, but during that century, they apparently disappeared (Lehtola, 2002, pp. 28-29). The Christian rites of passage which change an individual's social status—such as baptism, confirmation and marriage-became 


\section{4}

important ceremonies. In the Konfirmanter [Candidates for Confirmation] woodcut, two girls and two boys walk towards the church over a wide snowy valley. The confirmation ceremony transformed the youth to adulthood, and new Sámi costumes were purchased for this rite of passage. In his Kjaerlighet på pinne [Love for Icicles], he depicts two children and a young boy who wants to lick ice. It has been sunny, but the nights are still cold. Yet, the winter has passed, spring is near, the atmosphere is calm and the children are enjoying a simple pleasure of life.

Savio lived his childhood and youth in the village which was highly influenced by the Laestadian movement, and alcohol, playing cards, yoiking [singing the Sámi way] and many other things were held to be sins and, they were told, would lead them to the flames of hell. Drinking and gambling were common problems for Sámi and Kven men. Savio clearly depicted such vice in his woodcuts, such as Aqua vita, where in the foreground of the composition, two drunk men are walking, empty wine bottles are in the snow and two men shown as black silhouettes are walking away with liquor bottles in their hands; and Friends, where again two men with liquor bottles are shown under a full moon lighting the polar night. However, in Card Players, he created a scene of summer fun with five men sitting in a circle, where the atmosphere is focused and intense. Savio wanted to show a range of feelings and behaviour in the Sámi and that, as in any group of people, there were both good and bad individuals. There could be deep anger, as in his Rivaler [Rivals], or deep feelings of inferiority, such as in the woodcut Sjalusi [Jealousy]. The shapes of both of these woodcuts are sharp and angular, the sky and surroundings are black and the mood is oppressive.

Sometimes, Savio had to deal with his own feelings, especially with his experience of loneliness. He often felt alone, as he represented a double minority: his mother was a Sámi and his father a Kven, and he was a teetotaller who had been educated by his religious grandparents. Savio was not a bohemian artist at all. He did not drink alcohol, he believed in God and he was an outsider in Oslo's art community (Nerhus, 1982, pp. 66, 91). When he was in Finnmark, people felt him to be too educated and therefore avoided him. His own loneliness can easily be seen in his woodcut Okto [Alone], where the lonely reindeer stands on the top of the hill and the sky behind the reindeer is in flames. A similar atmosphere exists in the woodcuts which represent a lonely and single tree on a windy and rough slope of the fell. Savio used nature to depict and reflect his own emotions and internal spaces of the soul and the experiences of other human beings.

The theme of many of Savio's woodcuts is the wolf: for example, Gumppet ja bohccot I [Wolf and Reindeer I], Gumppet, sápmelas, heargi [Wolf, Sámi and Reindeer], Jompa gumppiin [Jompa with Wolf], where a Sámi is fighting with a wolf and Badjeeatnamiidda [Crossing the Plains]. The wolf motif has been interpreted to represent the Norwegianisation policy which threatened the life and existence of the Sámi people (Rasmussen, 2005, p. 13). A reindeer is a symbol of the Sámi culture. The Sámi did not accept cultural subjugation, but they continued on with their own lives and culture, as evidenced by taking good care of their reindeer and driving away the wolves. His portrayal of the life of the Sámi people could very well be a sign of Savio's search for his own identity and his desire to make the Sámi visible and strengthen their identity.

In 1934, Savio stayed for some time in Munich and Cologne on his way to Paris, where he lived until the summer of 1936 and possibly studied art (Rasmussen, 2005, p. 90). It had to be a shock to him to realise there was a negative reaction against the art of the German expressionists and Edvard Munch, whom he respected highly. In 
1934, Adolf Hitler declared that there was no place for modernism and critical contemporary art, and they were banned in Germany and called entarte Kuns [degenerate art]. Those who were identified as degenerate artists were subjected to sanctions. These included being dismissed from teaching positions, being forbidden to exhibit or to sell their art and, in some cases, being forbidden to produce art. Degenerate artworks were eliminated from the German collections and museums, and, for example, 38 artworks produced by Munch were sold off in 1937 (Stang, 1980, pp. 278, 282).

Savio was multilingual: he could speak Sámi, Finnish and Norwegian, and understand Swedish. He had studied English and German (Moksnes Gjelsvik, 2012, p. 29). He had experienced minority contempt and was familiar with the harsh Norwegianisation policy. Visiting Europe in the mid-1930s, he became aware of the Nazi government's actions against art and the racial theories they supported. However, laughter and irony alleviate fear and frustration and add to resilience. Savio had a satirical or ironic attitude against racial ideas when he made the woodcut Hoppla vi lever! [Happy Days!], where naked Black people dance on the beach somewhere in tropical Africa. Similar to the African tribes, the Sámi were considered as relics and primitives, incapable of intellectual abstract analysis and philosophy. These Aboriginal people were thought to be innocent and unaware, just like happy children.

\section{Conclusion}

My main question concerned how Savio used his art as a tool for decolonisation in the 1920s and 1930s, and I attempted to answer it using interdisciplinary research. My research choices proved to be effective, and the Indigenous research offered me the ethical guidelines and tactics for determining my own position in relation to the Sámi culture. Different perspectives on art history—such as the iconological, semiotic and narrative-supported the analysis of Savio's woodcuts and offered historical and societal contexts. Sámi research was a necessity for understanding the way of life and culture of Sámi people. Unfortunately, I have only studied the basics of the Sámi language, and I know only the grammatical structure of the language. Better knowledge of the language would have deepened my understanding of Sámi culture.

The portrayal of the Sámi in Norwegian art has been and remains an exception, and artists have only been interested in depicting fishermen of the Arctic Ocean, the rugged coastline and mountain scenery. Savio was the first artist to focus on portraying the Sámi in Norway. He showed courage in this, and he never took the position that the Sámi were racial victims by selecting them as the subject of his art. Instead, he wanted to prove that Sámi culture was worthy of preservation and further development, and to influence the opinions of the public and get them to feel empathy for the Sámi and their culture. He did this during the early decades of the 1900s. However, at that time, there were also increasing conflicts between the economies of the majority and minority populations-a growing industrial community with increasing class polarisation, dependence on global business and, during the Nordic governments' active assimilation or isolation policies, the awakening activism of the Sámi people.

Savio's artistic work of that time and the political activity supported each other: if Sámi issues had not been discussed, art would not have been discussed, either, and it was important to the Sámi for their art to become more prominent and widely known. Art increased the Sámi people's feelings of solidarity, creating and strengthening their identity. It also made clear that the Sámi were not a primitive relic, but a 


\section{Tuija Hautala-Hirvioja}

people capable of producing culture and art, who had the right to an existence and a language of their own. The critics of his exhibitions were positive. Like the art of his role model Turi, Savio's woodcuts originated from the inside, as they were subjective and expressive.

With his art, he positioned the Sámi as subjects. He depicted Sámi people as actors, not only as anthropologically interesting objects. Even though he died young, Savio showed that a Sámi could become a professional artist and find respect for his art, and that his works could become part of museum collections: in 1994, the Saviomuseet [Savio Museum] was established in Kirkenes. Savio's art is just as important for contemporary Sámi artists. Today, many Sámi artists, such as Marja Helander, Outi Pieski, Máret Ánne Sara and Anders Sunna, highlight in their art the problems of land ownership and fishing rights as well as the effects of climate change on the lives of Indigenous peoples. Anders Sunna described his painting Colonialism Inc. (2016, painting, $244 \times 600 \mathrm{~cm}$; see Skancke Pedersen, 2016, p. 110):

In this painting I also want to quote an artist that I looked up to as a child. I inserted the woman from the woodcut Gánda ja nieida [Boy and Girl] by John Savio. A time travel, but by different means of transport. To move forward you need to have looked back.

\section{Notes}

1. The exhibition was taken to Finland, Norway, Sweden and Germany. The curators also edited the exhibition catalogue.

2. The Finno-Ugrian peoples or Finno-Ugric peoples are the peoples of Northeastern Europe, North Asia and the Carpathian Basin. They speak Finno-Ugric languages or languages of the Uralic family. The Uralic languages form a language family of 38 languages spoken by approximately 25 million people. The Uralic languages with the most native speakers are Hungarian, Finnish and Estonian, while other significant languages are Sámi and the languages spoken in Siberia like Erzya, Moksha, Mari, Udmurt and Komi (Uralilaiset kansat. M.A. Castrén seura, 2020).

3. Lapp is the old name of the Sámi given by others. The English word Saami refers to all Saami languages, and Sámi denotes the most widely spoken of these languages, North Sámi. Saami is based on the word Sápmi, which exists in all Saami languages and means Saami, Saami language and Saami land (Ranta \& Kanninen, 2019, p. 21). I am using the word Sámi, because John Savio spoke North Sámi language.

\section{References}

Aamold, S. (2017). Representing the hidden and the perceptible: Johan Turi's images of Sápmi. In S. Aamold, E. Haugdal, \& U. Angkjär Jörgensen (Eds.), Sámi art and aesthetics contemporary perspectives (pp. 69-97). Aarhus University Press.

Abiel, R. (1993). John Andreas Savio: The Sami artist of Norway. Savio Art Museum.

Ahvenjärvi, K. (2017). Päivitettyä perinnettä. Saamelaisen nykyrunouden saamelaiskuvastoja [Updated tradition: Sámi imagery in contemporary Sámi poetry] [Doctoral dissertation, University of Jyväskylä]. Studies in Humanities. https://jyx.jyu.fi/handle/123456789/54273

Alho, O., Hawkins, H., \& Vallinsaari, P. (1999). Finland: A cultural encyclopedia. Finnish Literature Society.

Bal, M. (2020). Preface of essays in visual semiotic of narrative analysis. www.miekebal.org/ publications/books/semiotics-of-narrative/

Bal, M., \& Bryson, N. (1991). Semiotics and art history. The Art Bulletin, 73(2), 174-298. 
Bang, N. C. (2002). En Savio—samlings tillblivelse [The Savio collection]. In K. Haukelid (Ed.), John Andreas Savio (pp. 5-15). Oslo Kunstförening.

Bergmann, S. (2009). Så främmande det lika. Samisk konst i liuset av religion och globalisering [It's so strange: Sámi art in the light of religion and globalization]. Tapir Akademisk Forlag.

Berntsen, A., \& Parmann, O. (1980). John Andreas Savio, Grafikk [John Andreas Savio, a graphic]. Dreyers Forlag.

Chilisa, B. (2012). Indigenous methodologies. SAGE Publishing.

D’Alleva, A. (2005). Methods \& theories of art history. Laurence King Publishing Ltd.

Dana, K. O. (2003). 'When a Lapp is out on the high fells': Literary voice and cultural identity for the Sámi. Scandinavian Studies, 75(2), 201-228.

Danbolt, G. (2001). Norsk kunsthistorie. Bilde og skultur frå vikingatida til idag [Norwegian art history: Visual art and sculpture from the Viking age to the present]. Det Norske Samlaget.

Gombrich, E. (1991). Art \& illusion: A study in the psychology of pictorial representation. Phaidon Press. (Original work published 1960).

Gullickson, C., \& Lorentzen, S. (2014). Sámi stories?: Art and identity of an Arctic people. Orkana Akademisk forlag AS.

Hautala-Hirvioja, T. (1999). Lappi-kuvan muotoutuminen suomalaisessa kuvataiteessa ennen toista maailmansotaa [Shaping the image of Lapland in Finnish visual arts before the Second World War] [Dissertation, Studies in Humanities 69, University of Jyväskylä].

Hautala-Hirvioja, T. (2014). Early Sámi visual artists: Western fine art meets Sámi culture. Barents Studies: Peoples, Economies and Politics, 1(1), 11-40.

Helander, E. (2000). Saamelainen maailmankuva ja luontosuhde [Sámi world view and nature relationship]. In I. Seurujärvi-Kari (Ed.), Beaivvi mánát. Saamelaisten juuret ja nykyaika (pp. 171-182). SKS [The Finnish Literary Society].

Helander, E., \& Kailo, K. (1999). Ei alkua ei loppua. Saamelaisten pubeenvuoro [No beginning, no end: Speech of the Sámi people]. Like Publishing.

Helander-Renvall, E. (2016). Sámi society matters. Lapland University Press.

Isaksson, P. (2001). Kumma kuvajainen. Rasismi rotututkimuksessa, rotuteorioiden saamelaiset ja suomalainen fyysinen antropologia [An odd reflection: Racism in racial studies, the Sami in racial theories and Finnish physical anthropology]. Kustannus Puntsi.

Isaksson, P., \& Jokisalo, J. (2005). Kallonmittaajia ja skinejä. Rasismin aatehistoria [Skullmeters and skins: History of racism]. Like Publishing.

Kent, N. (2014). The Sámi peoples of the North: A social and cultural history. C. Hurts \& Co. Ltd.

Kovach, M. (2010). Indigenous methodologies: Characteristics, conversations, and contexts. University of Toronto Press.

Kulonen, U.-M., Seurujärvi-Kari,I., \& Pulkkinen, R. (2005). The Saami: A cultural encyclopaedia. SKS [The Finnish Literary Society].

Kuokkanen, R. (1999). Etnostressistä sillanrakennukseen. Saamelaisen nykykirjallisuuden minäkuvat [From the ethnological stress to the bridge construction: The self-portraits of contemporary Sámi literature]. In M. Tuominen, S. Tuulentie, V.-P. Lehtola, \& M. Autti (Eds.), Pohjoiset identiteetit ja mentaliteetit 1. Outamailta tunturiin (pp. 95-112). Lapland.

Kuokkanen, R. (2007). Saamelaiset ja kolonialismin vaikutukset nykypäivänä [The Sámi and the effects of colonialism today]. In J. L. Kuortti, M. Lehtonen, \& O. Löytty (Eds.), Kolonialismi jäljet. Keskusta, periferiat ja Suomi (pp. 142-155). Gaudeamus.

Lehtola, V.-P. (2002). The Sámi people: Traditions in transition. Kustannus-Puntsi.

Lorck, A. M. (2002). Savio-den förste samiske kunstner på heltid [Savio: The first Sámi artist full time]. In K. Haukelid (Ed.), John Andreas Savio (pp. 19-26). Oslo Kunstförening.

Lähteenmäki, M. (2004). Kalotin kansaa. Rajankäynnit ja vuorovaikutus Pohjoiskalotilla 1808-1889 [The peoples of Lapland: Boundary demarcations and interaction in the North Calotte from 1808 to 1889]. SKS [The Finnish Literary Society].

Magga, P. (2013). Mikä tekee kulttuuriympäristöstä saamelaisen? [What makes the Sámi a cultural environment?]. In P. Magga \& E. Ojanlatva (Eds.), Ealli biras. Elävä ympäristö. 


\section{Tuija Hautala-Hirvioja}

Saamelainen kulttuuriympäristöohjelma [Ealli biras: Living environment: Sámi cultural environment program (pp. 10-13)]. Saamelaismuseosäätiö [Sámi Museum].

Moksnes Gjelsvik, M. (2012). John Savio-hans liv og kunst [John Savio: His life and art]. NT-Forlag.

Nerhus, H. (1982). John Andreas Savio. Same og kunster [John Andreas Savio: Sámi and artist]. Forlaget form og farge.

Panofsky, E. (1972). Studies in iconology: Humanistic themes in the art of the Renaissance. Icon editions. (Original work published 1939).

Ranta, K., \& Kanninen, J. (2019). Vastatuuleen. Saamen kansan pakkosuomalaistamisesta [Against the wind: On the forced Finnishization of the Sámi people]. Kustantamo S\&S.

Rasmussen, S. (2005). John Andreas Savio 1902-1938: En samik kunstner fra Sør-Varanger [John Anreas Savio 1902-1938: A Sámi artist from South-Varanger]. Saviomuseet.

Relph, E. (1986). Place and placelessness. Pion Ltd.

Seurujärvi-Kari, I. (2011). Alkuperäiskansatutkimus, alkuperäiskansaliike ja saamelaiset [Indigenous studies, Indigenous movement and Sámi]. In I. Seurujärvi-Kari, P. Halinen, \& R. Pulkkinen (Eds.), Saamentutkimus tänään (pp. 10-55). SKS [The Finnish Literary Society].

Skancke Pedersen, H. (Ed.). (2016). Áigemátki-Tidsreise-Time Travel. Davvi Girji.

Smith, L. T. (2012). Decolonizing methodologies: Research and Indigenous peoples (2nd ed.). Zed Books Ltd.

Solbakk, J. (2006). The Sámi people: A handbook. Davvi Girji Os.

Stang, R. (1980). Edvard Munch. Ihminen ja taiteilija [Edvard Munch: A human being and artist]. WSOY.

Store Norske Leksikon. (2020, February). Isak Saba. https://nbl.snl.no/Isak Saba

Sunna, H. (2006). Duodji Árbi Arvet Handicraft in the Sámi culture. Sameslöjdstiftelsen Sámi Duoji.

Topelius, Z. (1898, the first edition in 1893). Suomi 19:nnellä vuosisadalla [Finland in the 19th century]. WSOY.

Turi, J. (1979). Kertomus saamelaisista [The book of Sámi]. WSOY.

Uralilaiset kansat. M.A. Castrén seura. (2020, April). [Uralic peoples: The society of M.A. Castrén]. www.macastren.fi/uralilaiset_kansat/index.html

Valkonen, J., \& Valkonen, S. (2018). Viidon sieiddit-Saamelaisen luontosubteen undet mittasubteet [The new dimensions of the Sámi relationship with nature]. Lapland University Press.

Wallenius-Korkalo, S. (2014). Cultural, social and political ideas are often shared by religion. Barents Studies: Peoples, Economies and Politics, 1(2), 111-113.

Wa Thiong'o, N. (1986). Decolonising the mind: The politics of language in African literature. Heineman Educational Books Ltd.

Waziyatawin, Wilson, A., \& Yellow Bird, M. (2005). For Indigenous eyes only: A decolonization handbook. School of American Research Press.

Wilson, S. (2008). Research is ceremony: Indigenous research methods. Fenwood Publishing. 